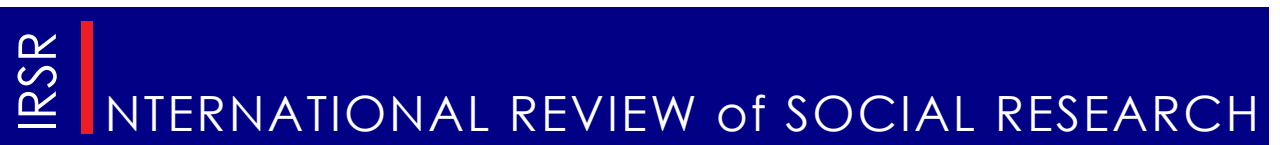

Volume 3, Issue 3, October 2013, 5-11

International Review of Social Research

\title{
A Brief Overview of Social Network Analysis and its Current State within Romanian Sociology
}

\author{
Marian-Gabriel HÂNCEAN ${ }^{*}$ \\ Department of Sociology \\ University of Bucharest
}

\begin{abstract}
The field of social network studies has been growing within the last 40 years, gathering scholars from a wide range of disciplines (biology, chemistry, geography, international relations, mathematics, political sciences, sociology etc.) and covering diverse substantive research topics. Using Google metrics, the scientific production within the field it is shown to follow an ascending trend since the late 60s. Within the Romanian sociology, social network analysis is still in his early spring, network studies being low in number and rather peripheral. This note gives a brief overview of social network analysis and makes some short references to the current state of the network studies within Romanian sociology.
\end{abstract}

Keywords: adaption, capitalization, coordination, Romanian sociology, social cohesion, social network analysis.

Within the last 40 years, (19702010), the number of scientific publications indexed by Google Scholar ${ }^{1}$, that included in their title the key-term social network hugely increased (Borgatti and Halgin, 2012: 3). The seminal book of Stanley Wasserman and Katherine Faust, Social Network Analysis: Methods and Applications, published in 1994 had in August, 2013, 16.336 citations. Another classic paper within the social network literature, authored by Mark Granovetter and published in 1973 (The Strength of Weak Ties) had, in August 2013, 25.266 citations $^{2}$, a growth of approximately 10.000 citations comparing to $2011^{3}$. The number of books published in English that have the terms social networks or

e-mail: gabriel.hancean $($ sas.unibuc.ro. Marian-Gabriel Hâncean is associate professor/lecturer of Organizational Sociology and Networks at University of Bucharest, Department of Sociology. He is also an affiliated member of International Network for Social Network Analysis and of Romanian Sociological Society. His main research stream focuses on understanding organizational performance from a social network perspective. 


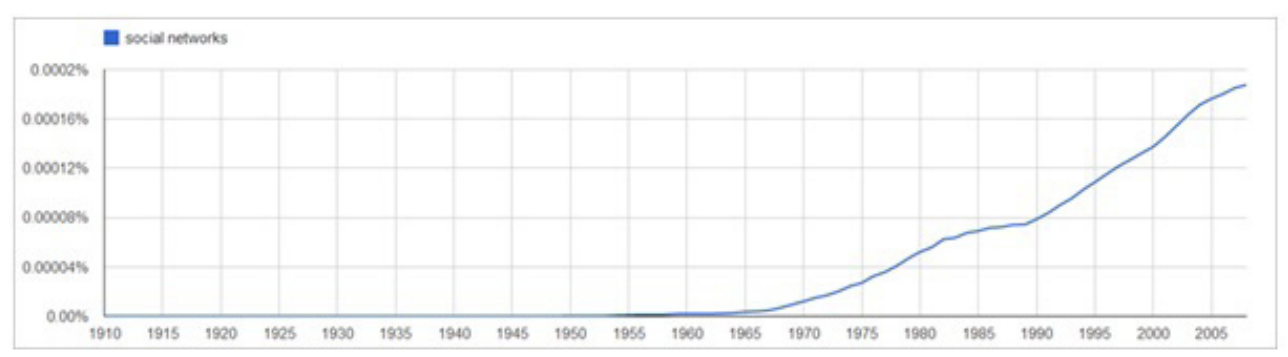

Figure 1. The growth in the number of Google indexed books containing social networks in their title (within the last 100 years)

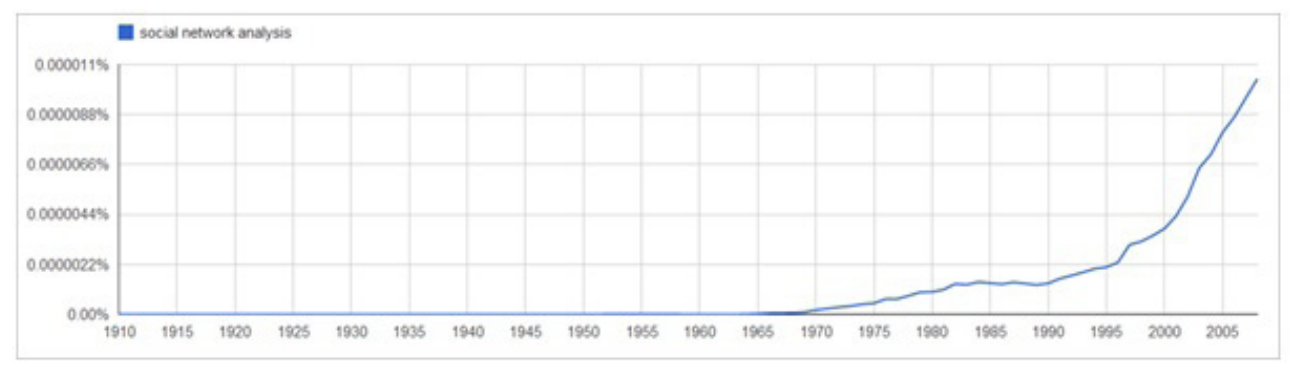

Figure 2. The growth in the number of Google indexed books containing social network analysis in their title (within the last 100 years)

social network analysis in their title significantly increased starting from the second half of the 70s and kept an ascending trend (Figures 1 and 2). Moreover, The Sunbelt International Conference of the International Network for Social Network Analysis gathered in Hamburg (Germany), in 2013, at the XXXIII edition, a peak of 1.157 participants that gave 750 paper presentations and discussed over 100 posters ${ }^{4}$.

As shown, the scientific production in the field of social networks has been extremely dynamic and can be plotted on a straight line. Research on social networks was boosted by the development, starting from the early $90 \mathrm{~s}$, of special software packages (Huisman and van Duijn, 2011). The development of relational data analysis software packages has had a direct impact on the field allowing for a rapid progress from small-group research to large relational data sets (several thousands of nodes or more).

Internationally, the field of social networks is still growing, gathering scholars from a widerange of disciplines (biology, chemistry, geography, international relations, mathematics, political sciences, sociology etc.). Within the Romanian sociology, it is difficult to estimate the number of studies that approached social network topics. However, intuitively, I argue that the field is still in his early spring, even if during the communist regime a few isolated research projects with social network oriented topics can be spotted. I would highlight two publications edited during the late 60s and early 70s. In 1967, Achim Mihu published Sociometry. A Critical Approach (Sociometria. Eseu critic, in Romanian), a substantive book that 
supported author's personal perspective on the seminal work of Jacob L. Moreno in the field of sociometry. In 1971, Mihaela Rob (Vlasceanu) reported probably the first Romanian social network analysis, Optimality and Efficiency within the Educational Process (Optimizare și Eficiență în Activitatea Instructiv-Educativă, in Romanian). She conducted a social network analysis on groups of students, analyzing the structure of studentprofessor relationships.

The first international conference on social networks, the Social Network Environments Conference ${ }^{5}$ (SoNetE) was organized in Bucharest in 2013, by the Sociology Department of University of Bucharest and the Department of International Relations and European Studies of National University of Political Studies and Public Administration (SNSPA). SoNetE gathered 70 participants, from several national and international universities, such as University of South Carolina, North Dakota State University, University of New York, Loyola University Maryland, University of Bucharest, SNSPA, Sapientia Hungarian University of Transylvania. During the 5 days of SoNetE, participants gave 15 research presentations (early stage presentations, papers close to completion, on-going researches etc.).

SoNetE aimed two main objectives. The first was to enhance the capacity of the Romanian academic community to link to the international research communities and research streams (in the field of inter- and intraorganizational social network research). The second was to seek out opportunities and venues for Romanian researchers to develop collaborative activities with business, public and nonprofit sectors' representatives. To target these objectives, SoNetE provided multiple formats for discussions: research presentations (e.g. early stage research presentations, papers close to completion etc.), future paths-round tables (e.g. representatives of academic and non-academic communities uncovered problems and discussed possible solutions as to enhance Romanian academic community's research capabilities and streams), lectures (e.g. how academic social research might meet non-academic environments' needs for knowledge) and keynote addresses (i.e. those given by Pamela Emanuelson, Yamilette Chacon, Rebecca Morton and Ulrich Teichler).

Social network analysis (SNA) proves to be extremely fertile in explaining a wide area of social phenomena (Borgatti and Foster, 2003). SNA has been used in the study of resource distribution (the inequalities in capitalization; see Brass and Krackhardt, 2012; Granovetter, 1973), social cohesion (actors' similarities, contamination, structural equivalence, social influence; see Barash, 2011; Burt, 1987; Friedkin and Johnsen, 1999; Monge and Contractor, 2003), coordination (integration; see Emanuelson, 2005; Willer, 1999) and adaption (isomorphism, mimetic behavior, benchmarking; see DiMaggio and Powell, 1983; Powell and DiMaggio, 1991; Galaskiewicz and Burt, 1991).

In the medical field, SNA has been applied, for instance, in the study of obesity (Christakis and Fowler, 2007) or the circulation of sexually 
transmitted diseases (Borgatti, 1995). In the field of intelligence, it has been applied in the study of dark networks (Borgatti, 2003), illegal behavior, biological or chemical simulated threats (Carley, Altman, Casman, Fridsma, Yahja, Chen, Kaminsky, and Nave, 2006). Furthermore, in this respect, different software packages have been developed as to support research and theoretical work, such as KeyPlayer 1. In the field of business, dependence and interdependence ties among organizations have been analyzed as to identify ways for increasing organizational performance. Furthermore, SNA was effective in the study of alliances and the coalition emergence, as well as in the study of illegal organizational networks.

As shown by Marsden (1990), Wasserman and Faust (1994), Krackhardt (2010) or Henning, Brandes, Pfeffer and Mergel (2013), social network studies differ by their units of observation (dyads, triads, whole networks). SNA is applied at the level of ties and relationships among individual (persons) or aggregate (communities, groups, countries etc.) actors. Moreover, social network studies explored both the antecedents the causes that trigger specific network configurations, and consequences - the effects that social networks produce; e.g. resource distribution, success of failure (see Brass, Galaskiewicz, Greve and Tsai 2004, for a review). There are different theoretical models that explain network emergence. For instance, Krackhardt (1994) explained the emergence of informal intraorganizational networks by stressing three factors: work dependencies, intensity of relations and the corresponding affectivity conveyed by working relationships (positive or negative affectivity). From an organizational point of view, some network studies investigated the effects that downsizing has on the structuring of intra-organizational networks. Individual success was explained by references to the nature of social ties (e.g. strong and weak ties, bridge ties) and to the shapes of networks (dense networks or networks with many structural holes). Within organizations and working groups, some models explained satisfaction, power, performance, non-ethic behavior or turnover as effects of social networks.

Social communities have been investigated from a structural perspective, stressing their similarity to the characteristics of specific graphs such as small world, random or regular graphs (Travers and Milgram, 1969; Buchanan, 2002; Watts and Strogatz, 1998). In this perspective, network studies explored, for instance, collaboration networks (Hoffman, 1999; Moody, 2004), movie industry collaborations or interlocking directorates.

Social networks have been also studied under experimental settings. Significant research topics for social life (such as trust emergence, cooperation enhancement or the freeriding problem) have been investigated by exploring different network configurations within experimental laboratory environments (Willer, 1999). From this perspective, there is a consistent body of knowledge treating research themes as the power and coercion relationships (Emanuelson, 2005; Emanuelson and Willer, 2009), the effects of informational 
asymmetries, the impact of reputation, the emergence of personalized exchange networks, generalized reciprocal exchange networks.

Beyond its methodological and ethical limitations (Scott and Carrington, 2012; Borgatti and Molina, 2003), SNA is effective in supporting explanations for academic, governmental and business problems. Within business environments, social network studies help increasing organizational performance or reaching a better market structural position. Within the area or public organizations and governance, SNA might lead to a better public resource exploitation and public program implementing.

\section{Notes}

${ }^{1}$ See http://scholar.google.ro/ (Retrieved: October, 5, 2013)

2 The citation number according to Google Scholar (Retrieved: August 30, 2013)

${ }^{3}$ Borgatti and Halgin (2011) reported over 14.000 citations, using a measurement tool the Google Scholar.

${ }^{4}$ See INSNA, http://hamburg-sunbelt 2013.org/ (Retrieved: August 30, 2013).

5 Additional information is available on sonete.sas.unibuc (Retrieved: October 20, 2013).

Author's note: This paper is built on sections from Hâncean (2014, forthcoming).

\section{References}

Barash, V. (2011) The Dynamics of Social Contagion. Doctoral Thesis. Cornell University.

Borgatti, S. P. (1995) 'Centrality and AIDS'. Connections, 18(1): 112-115.

Borgatti, S. P. (2003) 'The Key Player Problem'. In Breiger, R., K. Carley and P. Pattison (eds.) Dynamic Social Network Modelling and Analysis: Workshop Summary and Papers, pp. 241-252. Washington, D.C.: National Academy Press. Borgatti, S. P. and D. Halgin (2011) 'On Network Theory'. Organization Science, 22(5): 1168-1181.

Borgatti, S. P. and J. L. Molina (2003) 'Ethical and Strategic Issues in Organizational Social Network Analysis'. The Journal of Applied Behavioral Science, 39(3): 337-349.

Borgatti, S.P. and P.C. Foster (2003) 'The Network Paradigm in Organizational Research: A Review and Typology'. Journal of Management, 29(6): 991-1013 Brass, D. J., D. M. Krackhardt (2012) 'Power, Politics, and Social Networks in Organizations'. In G. R. Ferris and D. C. Treadway (eds.) Politics in Organizations. Theory and Research Considerations, pp. 355-375. New York \& London: Routledge, Taylor and Francis Group.

Brass, D. J., J. Galaskiewicz, H. R. Greve and W. Tsai (2004) 'Taking Stock of Networks and Organizations: A Multilevel Perspective'. Academy of Management Journal, 47(6): 795-817.

Buchanan, M. (2002) Nexus. Small Worlds and the Groundbreaking Science of Networks. New York: W. W. Norton \& Company, Inc.

Burt, R. S. (1987) 'Social Contagion and Innovation: Cohesion versus Structural 
Equivalence'. American Journal of Sociology, 92(6): 1287-1335

Carley, K., N. Altman, E. Casman, D. Fridsma, A. Yahja, L-C Chen, B. Kaminsky, and D. Nave (2006) 'BioWar: Scalable Agent-Based Model of Bioattacks'. IEEE Trans. on Systems, Man, and Cybernetics, 36(2): 252-265.

Christakis, N.A. and J.H. Fowler (2007) 'The Spread of Obesity in a Large Social Network over 32 Years'. The New England Journal of Medicine, 357(4): 370-379. DiMaggio, P.J. and W.W. Powell (1983) 'The Iron Cage Revisited: Institutional Isomorphism and Collective Rationality in Organizational Fields'. American Sociological Review, 48(2): 147-160.

Emanuelson, P. and D. Willer (2009) 'One-Shot Exchange Networks and The Shadow of the Future'. Social Networks, 31(2): 147-154.

Emanuelson, P. (2005) 'Improving the Precision and Parsimony of Network Exchange Theory: A Comparison of Three Network Exchange Models'. Current Research in Social Psychology, 10(11): 149 - 165

Friedkin, N.E. and E.C. Johnsen (1999) 'Social Influence Networks and Opinion Change'. Advances in Group Processes, 16: 1-29.

Galaskiewicz, J. and R.S. Burt (1991) 'Interorganization Contagion in Corporate Philanthropy'. Administrative Science Quarterly, 36(1): 88-105.

Granovetter, M.S. (1973) 'The Strength of Weak Ties'. American Journal of Sociology, 78(6): 1360-1380.

Hâncean, M-G. (2014) Rețele sociale. Teorie, metodologie, aplicații. MS. Henning, M., U. Brandes, J. Pfeffer and I. Mergel (2013) Studying Social Networks. A Guide to Empirical Research. Frankfurt/New York: Campus Verlag. Hoffman, P. (1999) The Man Who Loved Only Numbers. The Story of Paul Erdos and the Search for Mathematical Truth. London: Fourth Estate.

Huisman, M. and M.A.J. van Duijn (2012) 'A Reader's Guide to SNA Software'. In Scott, J. and P.J. Carrington (eds.) The Sage Handbook of Social Network Analysis, pp. 578-600. London: Sage.

Krackhardt, D. (1994) 'Constraints on the Interactive Organization as an Ideal Type'. In Heckscher C. and A. Donnellan (eds.) The Post-Bureaucratic Organization, pp. 211-222. Beverly Hills, CA: Sage.

Krackhardt, D. (2010) 'Social Networks'. In Levine J.M. and M.A. Hogg (eds.) Encyclopedia of Group Processes and Intergroup Relations, pp. 817-821. Los Angeles: Sage.

Marsden, P. (1988) Homogeneity in Confinding Relations. Social Networks, 10: 57-76.

Mihu, A. (1967) Sociometria. Eseu critic. Bucuresti: Editura Politică.

Monge, P.R. and N.S. Contractor (2003) Theories of Communication Networks. New York: Oxford University Press.

Moody, J. (2004) 'The Structure of a Social Science Collaboration Network:

Disciplinary Cohesion from 1963 to 1999'. American Sociological Review, 69(2): 213-238.

Powell, W.W. and P. DiMaggio (1991) The New Institutionalism in Organizational Analysis. Chicago: University of Chicago Press.

Rob (Vlăsceanu), M. (1971) Optimizare și Eficiență în Activitatea Instructiv- 
Educativă. Bucuresti: Universitatea din Bucuresti. Lucrare de licenta.

Scott, J. and P.J. Carrington (eds.) (2012) The Sage Handbook of Social Network Analysis. London: Sage.

Travers, J. and S. Milgram (1969) 'An Experimental Study of the Small World Problem'. Sociometry, 32(4): 425-443.

Wasserman, S. and K. Faust (1994) Social Network Analysis. Methods and Applications. New York: Cambridge University Press.

Watts, D. J. and S. H. Strogatz (1998) 'Collective Dynamics of 'Small-World'

Networks'. Nature, 393: 440-442.

Willer, D. (1999) Network Exchange Theory. Westport: Praeger. 
